\title{
Effect of Vegetable Oil Fortified Feeds on the Content of Fatty Acids in Breast and Thigh Muscles in Broiler Chickens
}

\author{
Tereza Krejčí-Treu, Eva Straková, Pavel Suchý, Ivan Herzig \\ Department of Nutrition, Animal Husbandry, and Animal Hygiene, Faculty of Veterinary Hygiene and Ecology, \\ University of Veterinary and Pharmaceutical Sciences Brno, Czech Republic
}

Received June 24, 2009

Accepted October 21, 2009

\begin{abstract}
The main objective of this work was to compare the effect of six vegetable oils added to feeding mixtures that were administered to broiler chickens on the content of major fatty acids in chicken meat. The experiment started with 90 one-day-old Ross 308 meat hybrid male chickens that were divided into six groups. Chickens were fed complete feeding mixtures for the prefattening (BR1), fattening (BR2), and post-fattening (BR3) of broiler chickens. The BR1 feeding mixture was administered to chickens aged 1-10 days, the BR2 feeding mixture was given from Day 11 to Day 30, and the BR3 feeding mixture was then administered until Day 42. The BR1 feeding mixture that was administered to all six groups during the first ten days of the experiment was supplemented with soybean oil. BR2 and BR3 feeding mixtures used to feed chickens aged 11-42 days were fortified with soybean oil (SO Group), rapeseed oil (RO Group), sunflower oil (SFO Group), flaxseed oil (FO Group), olive oil (OO Group), and evening primrose oil (EPO Group). The vegetable oils used differed by the composition of fatty acids, particularly by the content of oleic acid, linoleic acid, $\alpha$-linolenic acid. The use of the above-described experimental diets in young broilers from Day 11 to 42 had a significant effect on the content of fatty acids in the fat from breast and thigh muscles. The content of $\alpha$-linolenic acid in breast and thigh muscles of broilers that received the feed containing flaxseed oil $(21.16 \mathrm{~g} / 100 \mathrm{~g}$ of oil and $17.13 \mathrm{~g} / 100 \mathrm{~g}$ of oil, respectively) significantly increased $(p \leq 0.01)$. The highest content of linoleic acid $(p \leq 0.01)$ in breast and thigh muscles was found in chickens that were fed the feed containing primrose oil $(59.13 \mathrm{~g} / 100 \mathrm{~g}$ and $51.71 \mathrm{~g} / 100 \mathrm{~g})$. A significant increase $(p \leq 0.01)$ in the level of oleic acid was detected in both breast and thigh muscles of broilers that received olive oil fortified feed (52.44 $\mathrm{g} / 100 \mathrm{~g}$ and $43.70 \mathrm{~g} / 100 \mathrm{~g}$ of oil). No significant variation was found in the content of palmitic acid and palmitooleic acid. The levels of oleic acid, linoleic acid and $\alpha$-linolenic acid in feeding mixtures correlated with those found in breast and thigh muscles $(\mathrm{r}=0.88 ; 0.94$ and $0.99 ; \mathrm{r}=$ $0.99 ; 0.98$ and 0.99$)$.
\end{abstract}

The fattening of chickens, oleic acid, linoleic acid, $\alpha$-linolenic acid, stearic acid, palmitic acid, palmitoleic acid, arachidonic acid

Fat as one of the essential substances in human and animal nutrition is an integral component of most foodstuffs and feeds. Fat is particularly regarded as energy-yielding nutrient. In recent years, attention has been focused on the dietetic and health effects of fat. Dietetic effects of fat and oil depend primarily on the levels of individual fatty acids and on the mutual ratios of fatty acids. The World Health Organization (WHO 2003) recommends that for humans fat should represent $15-30 \%$ of the overall energy intake, of which saturated fatty acids should account for less than $10 \%$, polyunsaturated fatty acids (PUFAs) for $6-10 \%$, PUFAs $n-6$ for $5-8 \%$, PUFAs $n-3$ for $1-2 \%$, and trans fatty acids for less than $1 \%$. WHO recommendations are based on confirmed correlation between the diet and the occurrence of lifestyle diseases. One of the possible approaches that allow to increase the dietetic value of fat in a foodstuff originating from animals is to modify the composition of fatty acids in fat through a diet designed for the respective animal species intended for human nutrition.

Fat and oil in poultry diets serve as a source of energy. Their energy value is approximately twice as high as that of other nutrients present in feeding mixtures. Feeding mixtures usually

Address for correspondence:

Ing. Tereza Krejčí-Treu

Department of Nutrition, Animal Husbandry and Animal Hygiene

Faculty of Veterinary Hygiene and Ecology

University of Veterinary and Pharmaceutical Sciences Brno, Czech Republic

Palackého 1-3, 61242 Brno, Czech Republic

Phone: +420 541562674

E-mail: treut@vfu.cz

http://www.vfu.cz/acta-vet/actavet.htm 
contain fats (oils) from different sources, which contributes to variations in chemical and nutritional value (Wiseman et al. 1998). Originally, animal-based fat was a major source of fat in poultry diet (Leeson and Summers 2005). Efforts have been made to use sources from the increasing production of oil plants and oil (intended to satisfy the current demand for oils in human nutrition) to produce feeding mixtures, provided this is cost-effective compared to animal fat (Thacker et al. 1994). Recently, the use of plant oils has also been justified with regard to the demanding requirements for food safety.

It is generally assumed that the content of fatty acids in the meat of food animals (including broiler chickens) depends largely on the content and composition of these acids in the diet (Schiavone et al. 2004; Aldai et al. 2008; Zelenka et al. 2008). In monogastric animals, the profile of fatty acids in muscles and fat can be influenced relatively easily since fatty acids from a feed are absorbed unchanged in the small intestine. Fat such as subcutaneous fat, intermuscular fat and intramuscular fat is usually present as triacylglycerol or as phospholipid being part of cell membranes. The composition of fatty acids in phospholipids in meat is relatively constant whereas the variability of fatty acids in triacylglycerols is rather high and can be modified easily by a diet. For this purpose, feeds containing high levels of PUFAs are used, for example vegetable oils, oil plant seeds, fish meal, and fish oil (Barton et al. 2007; 2008).

The main objective of this work was to compare the effect of six vegetable oils added to feeding mixtures that were administered to broiler chickens on the content of major fatty acids in chicken meat.

\section{Materials and Methods}

The experiment included a total of 90 one-day-old Ross 308 meat hybrid male chickens whose average live weight was $42 \mathrm{~g}$. Chickens were randomized into six groups, each containing 15 birds. Biological testing was performed in the accredited experimental enclosure of the Institute for Nutrition, Animal Husbandry, and Animal Hygiene, University of Veterinary and Pharmaceutical Sciences Brno. The experiment was run in compliance with the technological procedure for the fattening of Ross 308 combination broilers. Chickens in individual groups were reared separately in pens sized $3.7 \mathrm{~m}^{2}$, on deep bedding, at a density of 1 chicken per $0.25 \mathrm{~m}^{2}$. During the fattening period, the light regimen based on $23 \mathrm{~h}$ of light and $1 \mathrm{~h}$ of dark was used. The temperature at the beginning of the experiment was $31.5^{\circ} \mathrm{C}$ and decreased to $22.5^{\circ} \mathrm{C}$ during the experiment. The temperature was maintained using electronic hen-like devices providing radiant heat.

Complete feeding mixtures for the pre-fattening, fattening, and post-fattening of broiler chickens were tested in the experiment. The feeding mixture for the pre-fattening period (BR 1) was administered to chickens from Day 1 to Day 10, the feeding mixture for the fattening period (BR 2) was used between Days 11 and 30 while the feeding mixture for the post-fattening period (BR 3) was the administered to broilers until the end of the experiment, i.e. until Day 42. The feed was administered through automatic feeders, water was provided from hat-like waterers, both ad libitum.

Until Day 10, chickens in all groups were fed the same feeding mixture for the pre-fattening period (BR 1) fortified with soybean oil. From Day 11 to Day 42, feeding mixtures for the fattening and post-fattening period were used, containing different oils: SO Group - soybean oil, RO Group - rapeseed oil, SFO Group - sunflower oil, FO Group - flaxseed oil, OO Group - olive oil, EPO Group - evening primrose oil. The content of fatty acids ( $\mathrm{g} / 100 \mathrm{~g}$ of oil) in complete feeding mixtures for the pre-fattening, fattening, and post-fattening of broiler chickens are listed in Table 1 .

The chemical composition of the feeding mixture for the pre-fattening period in $100 \%$ dry matter was as follows - CP (crude protein; g/ $/ \mathrm{kg}$ ) 233.2; fat $(\mathrm{g} / \mathrm{kg}$ ) 47.5; fibre $(\mathrm{g} / \mathrm{kg}) 30.3 ; \mathrm{NFE}$ (nitrogen-free extract; $\mathrm{g} / \mathrm{kg}$ ) 628.5; ash (g/kg) 60.5; BE (brutto energy; MJ/kg) 18.7; lysine (g/kg) 9.1.

The chemical composition of the feeding mixture for the fattening period at $100 \%$ dry matter in the sequence $\mathrm{SO}, \mathrm{RO}, \mathrm{SFO}, \mathrm{FO}, \mathrm{OO}, \mathrm{EPO}$ Groups was as follows - CP (g/kg) 227.8, 230.3, 233.1, 230.5, 227.2, 230,6; fat (g/ $\mathrm{kg}) 62.1,63.9,62.7,62.6,62.8,61.8$; fibre $(\mathrm{g} / \mathrm{kg}) 28.5,27 ., 25.7,26.4,27.7,27.5 ; \mathrm{NFE}(\mathrm{g} / \mathrm{kg}) 624.2,621.8,619.4$, $622.7,625.4,624.4 ;$ ash $(\mathrm{g} / \mathrm{kg}) 57.5,57,59.1,57.9,56.9,55.7 ; \mathrm{BE}(\mathrm{MJ} / \mathrm{kg}) 19.9,19.1,19,19,19.1,19.1 ; 1 y s i n e$ $(\mathrm{g} / \mathrm{kg}) 8,8,11,11.9,11.9,11.6$.

The chemical composition of the feeding mixture for the post-fattening period at $100 \%$ dry matter in the sequence SO, RO, SFO, FO, OO, EPO Groups was as follows - CP (g/kg) 193.3, 191.6, 192, 194.9, 193.8, 194; fat $(\mathrm{g} / \mathrm{kg}) 59.9,60.7,58.6,60.6,57.8,59.4$; fibre $(\mathrm{g} / \mathrm{kg}) 28.5,27.6,29,26.4,26.2,27.6 ; \mathrm{NFE}(\mathrm{g} / \mathrm{kg}) 668.8,670.1$, $670.5,668.1,672.5,670 ;$ ash $(\mathrm{g} / \mathrm{kg}) 49.5,50,49.9,50,49.8,50 ; \mathrm{BE}(\mathrm{MJ} / \mathrm{kg}), 18.9,18.8,18.8,18.7,18.8 ; \mathrm{Lysine}$ $(\mathrm{g} / \mathrm{kg}) 7.3,9.9,7.4,8.6,7.6,8.2$. 
Table 1. Content of fatty acids (in $\mathrm{g} / 100 \mathrm{~g}$ of oil) in complete feeding mixtures fed to broilers during the pre-fattening (BR 1), fattening (BR 2) and postfattening (BR 3) periods

\begin{tabular}{|c|c|c|c|c|c|c|}
\hline \multirow{2}{*}{ Fatty acids } & \multicolumn{6}{|c|}{ Plant oils } \\
\hline & $\mathrm{SO}$ & $\mathrm{RO}$ & SFO & FO & $\mathrm{OO}$ & EPO \\
\hline \multicolumn{7}{|l|}{ BR1 } \\
\hline C16:0 Palmitic acid & 10.93 & - & - & - & - & - \\
\hline C16:1 Palmitoleic acid & 0.25 & - & - & - & - & - \\
\hline C18:0 Stearic acid & 2.32 & - & - & - & - & - \\
\hline C18:1 Oleic acid & 19.65 & - & - & - & - & - \\
\hline C18:2 Linoleic acid & 45.77 & - & - & - & - & - \\
\hline C18:3 $\alpha$-linolenic acid & 4.05 & - & - & - & - & - \\
\hline C20:4 Arachidonic acid & 0.28 & - & - & - & - & - \\
\hline \multicolumn{7}{|l|}{ BR2 } \\
\hline C16:0 Palmitic acid & 10.33 & 7.26 & 7.89 & 7.90 & 11.32 & 8.09 \\
\hline C16:1 Palmitoleic acid & 0.11 & 0.19 & 0.10 & 0.09 & 0.44 & 0.08 \\
\hline C18:0 Stearic acid & 2.45 & 1.80 & 2.43 & 2.79 & 2.62 & 1.71 \\
\hline C18:1 Oleic acid & 20.62 & 45.34 & 20.32 & 18.40 & 52.44 & 11.65 \\
\hline C18:2 Linoleic acid & 47.80 & 26.67 & 55.52 & 24.50 & 19.63 & 59.13 \\
\hline C18:3 $\alpha$-linolenic acid & 4.06 & 3.95 & 1.46 & 21.16 & 1.39 & 1.33 \\
\hline C20:4 Arachidonic acid & 0.31 & 0.45 & 0.19 & 0.21 & 0.39 & 0.31 \\
\hline \multicolumn{7}{|l|}{ BR3 } \\
\hline C16:0 Palmitic acid & 10.25 & 8.23 & 8.26 & 8.24 & 10.34 & 8.59 \\
\hline C16:1 Palmitoleic acid & 0.13 & 0.20 & 0.13 & 0.13 & 0.35 & 0.11 \\
\hline C18:0 Stearic acid & 2.20 & 1.90 & 2.14 & 2.40 & 2.28 & 1.84 \\
\hline C18:1 Oleic acid & 23.96 & 39.90 & 22.81 & 22.15 & 43.70 & 18.06 \\
\hline C18:2 linoleic acid & 46.82 & 32.85 & 48.58 & 31.18 & 29.54 & 51.71 \\
\hline C18:3 $\alpha$-Linolenic acid & 5.39 & 5.07 & 3.45 & 17.13 & 3.53 & 3.22 \\
\hline C20:4 Arachidonic acid & 0.31 & 0.43 & 0.23 & 0.27 & 0.33 & 0.30 \\
\hline
\end{tabular}

$\mathrm{SO}$ - Soybean oil, RO - Rapeseed oil, SFO - Sunflower oil, FO - Flaxseed oil,

$\mathrm{OO}$ - Olive oil, EPO - Evening primrose oil

At the end of the experiment (42 ${ }^{\text {nd }}$ day) 10 chickens from each group were selected and killed; samples of breast (m. pectoralis) and thigh muscles ( $\mathrm{m}$. flexor crutis, $\mathrm{m}$. puboischiofemoralis, $\mathrm{m}$. femorotibialis, $\mathrm{m}$. iliotibialis) were collected from the left side of the carcass and analysed for the content of fatty acids. After sample homogenization, water was separated and fat was extracted followed by the esterification of fat to prepare a sample for analysis according to Hara and Radin (1978). Fatty acids in plant oils, breast and thigh muscles were determined using a gas chromatograph (GC 2010, Shimadzu).

On the basis of the contents of fatty acids in the used oils, seven fatty acids such as palmitic acid, palmitoleic acid, stearic acid, oleic acid, linoleic acid, $\alpha$-linolenic acid and arachidonic acid (Table 1) were evaluated in the samples of muscles. The contents of fatty acids are expressed in $\mathrm{g} / 100 \mathrm{~g}$ of fat in a sample.

The values found were processed using the statistical programme Statistica CZ, version 6 (StatSoft, Inc., 2001), arithmetic mean $(x)$, standard deviation $( \pm s)$ and correlation coefficient $(r)$ were calculated. The average values were tested on a particular level of significance $(p \leq 0.05$ and $p \leq 0.01)$.

\section{Results and Discussion}

Content of fatty acids in experimental feeding mixtures

The contents of selected fatty acids in complete feeding mixtures used in the individual phases of broiler fattening are listed in Table 1. In the pre-fattening period, broilers in all groups received the same feeding mixture containing soybean oil in which the highest contents were detected for linoleic acid and oleic acid (45.77 and $19.65 \mathrm{~g} / 100 \mathrm{~g}$ of oil, respectively).

In the fattening and post-fattening period (BR2 a BR3), the highest content in the SO Group was detected for linoleic acid (47.80 and $46.82 \mathrm{~g} / 100 \mathrm{~g}$ of oil) and oleic 
acid (20.62 and $23.96 \mathrm{~g} / 100 \mathrm{~g}$ of oil) whereas in the RO Group the highest content was found for oleic acid (45.34 and $39.90 \mathrm{~g} / 100 \mathrm{~g}$ of oil) with the lowest content detected for linoleic acid (26.67 and $32.85 \mathrm{~g} / 100 \mathrm{~g}$ of oil). The SFO Group was characterized by the highest content of linoleic acid (55.52 and $48.58 \mathrm{~g} / 100 \mathrm{~g}$ of oil) and oleic acid (20.32 and $22.81 \mathrm{~g} / 100 \mathrm{~g}$ of oil). In the FO Group the highest contents were detected in the BR2 and BR3 period for linoleic (24.50 and $31.18 \mathrm{~g} / 100 \mathrm{~g}$ of oil) and oleic acid (18.40 and $22.15 \mathrm{~g} / 100 \mathrm{~g}$ of oil). Flaxseed oil is also an important source of $\alpha$-linolenic acid $(21.16$ and $17.13 \mathrm{~g} / 100 \mathrm{~g})$. Olive oil (the OO Group) affected the content of oleic acid in BR2 and BR3 feeding mixtures (52.44 and $43.70 \mathrm{~g} / 100 \mathrm{~g}$ of oil); the content of linoleic acid also increased (19.63 and $29.54 \mathrm{~g} / 100 \mathrm{~g}$ of oil). Feeding mixtures enriched with evening primrose oil (the EPO Group) contained the highest content of linoleic acid (59.13 and $51.71 \mathrm{~g} / 100 \mathrm{~g}$ of oil) whereas oleic acid was found in lower concents (11.65 and $18.06 \mathrm{~g} / 100 \mathrm{~g}$ of oil). In all experimental diets, palmitic acid (7.26-11.32 g/100 g of oil) was ranked after the above-mentioned acids, and the contents of fatty acids such as palmitooleic, stearic and arachidonic acids were low (Table 1), ranging from $0.01 \mathrm{~g}$ to $2.79 \mathrm{~g} / 100 \mathrm{~g}$ of oil.

Parallel comparison of six plant oils in broiler chickens has not yet been reported. One oil at different levels was studied (Kim et al. 2008), 2-4 different kinds of fat were studied in a parallel experiment (Zollitsch et al. 1997; Schiavone et al. 2004), and the effect of n-3 and n-6 polyunsaturated fatty acids on the performance indicatos of chickens, sensory properties of chicken meat was investigated (Aldai et al. 2008; De Henauw et al. 2007; Kim et al. 2008; Zelenka et al. 2008).

The contents of PUFAs in poultry meat largely reflect those in the diet. The enrichment of a poultry product with n-3 PUFAs can provide a suitable source of these acids in human nutrition.

Content of fatty acids in breast muscles

The use of experimental feeding mixtures from Day 11 to Day 42 produced a significant effect on the composition of fatty acids in breast muscles in chickens (Table 2). Oleic

Table 2. Content of fatty acids in breast muscles from broiler chickens $(\mathrm{n}=10)(\mathrm{in} \mathrm{g} / 100 \mathrm{~g}$ of fat from breast muscles)

\begin{tabular}{|l|c|c|c|c|c|c|}
\hline \multirow{2}{*}{ Fatty acid } & \multicolumn{7}{|c|}{ Plant oils $(\mathrm{x} \pm \mathrm{s})$} \\
\cline { 2 - 7 } & $\mathrm{SO}$ & $\mathrm{RO}$ & SFO & FO & OO & EPO \\
\hline C16:0 & 16.54 & 14.61 & 15.35 & 16.66 & 16.32 & 16.25 \\
Palmitic acid & \pm 1.49 & \pm 1.81 & \pm 2.89 & \pm 1.00 & \pm 1.84 & \pm 2.49 \\
\hline C16:1 & 3.18 & 2.85 & 3.01 & 3.66 & 3.43 & 2.96 \\
Palmitoleic acid & \pm 1.00 & \pm 0.70 & \pm 1.37 & \pm 0.87 & \pm 1.00 & \pm 0.97 \\
\hline C18:0 & 4.89 & $4.47^{\mathrm{A}}$ & 4.88 & $4.96^{\mathrm{a}}$ & 4.58 & $5.24^{\mathrm{Bb}}$ \\
Stearic acid & \pm 0.47 & \pm 0.34 & \pm 0.43 & \pm 0.52 & \pm 0.51 & \pm 0.14 \\
\hline C18:1 & $27.24^{\mathrm{A}}$ & $28.89^{\mathrm{A}}$ & $24.31^{\mathrm{A}}$ & $26.90^{\mathrm{A}}$ & $36.34^{\mathrm{B}}$ & $23.34^{\mathrm{A}}$ \\
Oleic acid & \pm 3.26 & \pm 4.80 & \pm 6.61 & \pm 3.23 & \pm 5.07 & 4.29 \\
\hline C18:2 & $17.85^{\mathrm{BDF}}$ & $12.70^{\mathrm{ACDE}}$ & $16.06^{\mathrm{BCDE}}$ & $12.62^{\mathrm{ACDE}}$ & $11.30^{\mathrm{ACE}}$ & $20.43^{\mathrm{BF}}$ \\
Linoleic & \pm 2.39 & \pm 3.86 & \pm 2.32 & \pm 1.21 & \pm 1.43 & \pm 3.55 \\
\hline C18:3 & $1.45^{\mathrm{BCb}}$ & $1.25^{\mathrm{ABCDE}}$ & $0.73^{\mathrm{ACDE}}$ & $5.24^{\mathrm{F}}$ & $0.86^{\mathrm{ACDEa}}$ & $0.84^{\mathrm{ACDEa}}$ \\
$\alpha-$-linolenic acid & \pm 0.28 & \pm 0.31 & \pm 0.19 & \pm 0.93 & \pm 0.16 & \pm 0.19 \\
\hline C20:4 & $1.71^{\mathrm{a}}$ & $1.55^{\mathrm{a}}$ & $2.21^{\mathrm{B}}$ & $0.96^{\mathrm{A}}$ & 1.76 & $2.73^{\mathrm{Bb}}$ \\
Arachidonic acid & \pm 0.71 & \pm 0.45 & \pm 1.12 & \pm 0.40 & \pm 0.86 & \pm 0.83 \\
\hline
\end{tabular}

$\mathrm{x}=$ Mean; $\pm \mathrm{s}=$ Standard deviation; different letters - significance $p \leq 0.05={ }^{\mathrm{ab}} ; p \leq 0.01=\mathrm{AB}$

SO - Soybean oil, RO - Rapeseed oil, SFO - Sunflower oil, FO - Flaxseed oil,

$\mathrm{OO}$ - Olive oil, EPO - Evening primrose oil 
acid detected in the highest content in the OO Group's diet $(52.44$ and $43.70 \mathrm{~g} / 100 \mathrm{~g}$ of fat) also significantly $(p \leq 0.01)$ increased in breast muscles $(36.34 \mathrm{~g} / 100 \mathrm{~g}$ of fat $)$. The lowest content of oleic acid was found in the diet in the EPO Group (11.65 and $18.06 \mathrm{~g} / 100 \mathrm{~g}$ of fat), which was manifested by the lowest content of this acid in breast muscles $(23.34 \mathrm{~g} / 100 \mathrm{~g}$ of fat).

Linoleic acid showed the highest content in the diets in the EPO Group (59.13 and $51.71 \mathrm{~g} / 100 \mathrm{~g}$ of fat) whereas its lowest content was found in the diets in the OO Group (19.63 and $29.54 \mathrm{~g} / 100 \mathrm{~g}$ of fat). The composition of these fatty acids in breast muscles reflected that of the particular experimental diets $(20.43$ and $11.30 \mathrm{~g} / 100 \mathrm{~g}$ of fat in the EPO Group or the OO Group, respectively).

Flaxseed oil added to the diet in the FO group affected significantly the content of $\alpha$-linolenic acid (5.24 g/100 g of fat) compared to all other experimental groups (min. 0.73 in the SFO group, max. $1.45 \mathrm{~g} / 100 \mathrm{~g}$ of fat in the $\mathrm{SO}$ group).

Palmitic, palmitooleic, arachidonic acids were not found at significantly different levels in the diets which was also reflected in the contents of these fatty acids in breast muscles.

Strong correlation was found between the contents of oleic acid, linoleic acid, and $\alpha$-linolenic acid in feeding mixtures and those in breast muscles $(r=0.88 ; 0.94$ a 0.99$)$.

The levels of fatty acids in thigh muscles

Similar to breast muscles, experimental feeding mixtures fed to broiler chickens also affected the composition of fatty acids in thigh muscles. The contents of most fatty acids studied in thigh muscles, except for stearic acid and arachidonic acid, were increased compared to breast muscles (Table 3 ).

Oleic acid, which was detected in the OO Group's diet at the highest content, also showed the highest significant $(p \leq 0.01)$ value in thigh muscles $(42.29 \mathrm{~g} / 100 \mathrm{~g}$ of fat). The lowest content of oleic acid was found in the EPO Group's diet which was also observed in the content of this fatty acid in thigh muscles $(29.07 \mathrm{~g} / 100 \mathrm{~g}$ of fat $)$.

The highest content of linoleic acid was found in the diets in the EPO group, while in the diets in the OO group the content of this fatty acid was the lowest. The contents of these

Table 3. Content of fatty acids in thigh muscles from broiler chickens $(n=10)(\mathrm{in} g / 100 \mathrm{~g}$ of fat from thigh muscles)

\begin{tabular}{|l|c|c|c|c|c|c|}
\hline \multirow{2}{*}{ Fatty acids } & \multicolumn{7}{|c|}{ Plant oils $(\mathrm{x} \pm \mathrm{s})$} \\
\cline { 2 - 7 } & SO & RO & SFO & FO & OO & EPO \\
\hline C16:0 & 18.76 & $17.16^{\mathrm{a}}$ & 18.55 & 18.50 & $19.21^{\mathrm{b}}$ & 18.77 \\
Palmitic acid & \pm 1.66 & \pm 1.74 & \pm 1.00 & \pm 1.49 & \pm 0.90 & \pm 1.63 \\
\hline C16:1 & 4.58 & 4.54 & 4.66 & 5.09 & 5.10 & 4.28 \\
Palmitoleic acid & \pm 1.10 & \pm 0.68 & \pm 0.85 & \pm 0.80 & \pm 0.68 & \pm 0.83 \\
\hline C18:0 & $4.79^{\mathrm{BCEF}}$ & $4.03^{\mathrm{AE}}$ & $4.77^{\mathrm{BCEF}}$ & 4.53 & $4.29^{\mathrm{ABCE}}$ & $4.96^{\mathrm{BCF}}$ \\
Stearic acid & \pm 0.33 & \pm 0.45 & \pm 0.40 & \pm 0.48 & $\pm 0.33^{\mathrm{B}}$ & \pm 0.57 \\
\hline C18:1 & $33.20^{\mathrm{BDEb}}$ & $39.07^{\mathrm{C}}$ & $32.41^{\mathrm{ABDE}}$ & $31.99^{\mathrm{ABE}}$ & $42.29^{\mathrm{F}}$ & $29.07^{\mathrm{ADEa}}$ \\
Oleic acid & \pm 3.76 & \pm 4.12 & \pm 2.52 & \pm 2.01 & \pm 1.94 & \pm 2.79 \\
\hline C18:2 & $21.86^{\mathrm{BD}}$ & $14.42^{\mathrm{ACE}}$ & $21.47^{\mathrm{BD}}$ & $14.90^{\mathrm{ACE}}$ & $13.42^{\mathrm{ACE}}$ & $25.49^{\mathrm{F}}$ \\
Linoleic acid & \pm 2.07 & \pm 0.99 & \pm 2.66 & \pm 1.25 & \pm 1.37 & \pm 2.50 \\
\hline C18:3 & $1.87^{\mathrm{BC}}$ & $1.76 C^{\mathrm{BCb}}$ & $1.04^{\mathrm{ADE}}$ & $7.47^{\mathrm{F}}$ & $1.12^{\mathrm{ADEa}}$ & $1.11^{\mathrm{ADE}}$ \\
$\alpha-$-linolenic acid & \pm 0.21 & \pm 0.15 & \pm 0.16 & \pm 0.92 & \pm 0.15 & \pm 0.14 \\
\hline C20:4 & $1.20^{\mathrm{bcd}}$ & 0.82 & $1.13^{\mathrm{Bbd}}$ & $0.52^{\mathrm{Aac}}$ & $0.80^{\mathrm{bc}}$ & 1.38 \\
Arachidonic acid & \pm 0.42 & \pm 0.21 & \pm 0.40 & \pm 0.30 & \pm 0.29 & \pm 0.48 \\
\hline
\end{tabular}

$\mathrm{x}=$ Mean; $\pm \mathrm{s}=$ Standard deviation; different letters - significance $p \leq 0.05={ }^{\mathrm{ab}} ; p \leq 0.01=\mathrm{AB}$

SO - Soybean oil, RO - Rapeseed oil, SFO - Sunflower oil, FO - Flaxseed oil,

OO - Olive oil, EPO - Evening primrose oil 
fatty acids in thigh muscles were as expected $(25.49$ and $13.42 \mathrm{~g} / 100 \mathrm{~g}$ of fat in the EPO Group and in the OO Group).

Flaxseed oil added to the diet in the FO Group influenced the content of $\alpha$-linolenic acid not only in breast muscles but also in thigh muscles $(7.47 \mathrm{~g} / 100 \mathrm{~g}$ of fat) compared to the other experimental groups (min. $1.04 \mathrm{~g} / 100 \mathrm{~g}$ of fat in the SFO group, max. $1.87 \mathrm{~g} / 100 \mathrm{~g}$ of fat in the SO group).

The contents of palmitic, palmitoleic, arachidonic acids did not differ from those in the tested diets, as confirmed by their contents in thigh muscles.

The contents of oleic acid, linoleic acid, and $\alpha$-linolenic acid $(r=0.99 ; 0.98$ and 0.99$)$ in the feeding mixture for the post-fattening period correlated with those found in thigh muscles.

The range of plant oils characterized by different contents of some of the fatty acids fed in our experiment enable us to reveal the correlation between the contents of fatty acids in experimental feeding mixtures and those in breast and thigh muscles. The results show that the diet for broiler chickens suitably fortified with plant oils has a significant effect on the composition of fatty acids in breast and thigh muscles. This finding is in good agreement with the results reported by other authors (e.g. Schiavone et al. 2004; Aldai et al. 2008; Zelenka et al. 2008). Significant correlations were found for oleic acid, linoleic acid, and $\alpha$-linolenic acid, in both breast and thigh muscles. The contents of arachidonic acid were found to be influenced by the ratio of linoleic and $\alpha$-linolenic acids; this is an important finding confirmed by strong correlations $(\mathrm{r}=0.98 ; 0.84)$ in breast and thigh muscles. Sirri et al. (2003) and Du and Ahn (2003) reported that the content of arachidonic acid significantly decreased upon the supplementation of a feeding mixture with linoleic acid.

Eicosanoids are substances derived from arachidonic acid (unsaturated fatty acids containg 20 carbon atoms). Arachidonic acid is formed from linoleic acid and $\alpha$-linolenic acid. Serum concentrations of eicosanoid precursors, i.e. arachidonic acid and dihomogamma-linolenic acid, are directly related to the dietary intake of linoleic acid. The intake of linoleic acid below $2 \%$ of a total intake of energy is required to decrease the production of eicosanoids from arachidonic acid. Fortunately, a desirable effect can be achieved when the dietary intake of $\alpha$-linolenic acid is equal to the intake of ca $1 \%$ of a total energy (Lands et al. 1992). The group of eicosanoids includes prostaglandins, prostacyclins, thromboxanes, lipoxins and leukotrienes plus the derivatives of 12- hydroxyeicosatetraenic acid.

The n-6/n-3 PUFAs ratio (linoleic acid and arachidonic acid/ $\alpha-$ linolenic acid) was the most favourable in breast and thigh muscles in the FO Group (2.59 and 2.06) whereas the least favourable ratio was found in the EPO Group (27.57 and 24.21). The relatively favourable ratio of n-6/n-3 fatty acids was also found in the RO Group (11.4 and 8.66). Skrivan et al. (2000) demonstrated that the highest content of PUFAs was in samples from chickens receiving rapeseed oil. A rather narrow ratio was found in thigh muscles in all experimental groups. A decrease in the contents of saturated fatty acids and an increase in the content of n-3 PUFAs is desirable in respect to food safety and the $n-6 / n-3$ ratio should not exceed the value of 5 . In terms of human nutrition, the narrowed ratio indicates an increasing dietetic value. The current n-6/n-3 PUFAs ratio in European diets is within the range of 10-20:1, while the recommended ratio is 1-4:1 (Simopoulos 1999), and Okuyama et al. (1997) proposed a ratio of 2:1. Our experiments show that the FO experimental diet was very close to current recommendations.

\section{Vliv př́ídavku rostlinných olejů v krmných směsích na obsah mastných kyselin v prsní a stehenní svalovině brojlerových kuřat}

Tuky (oleje) jsou nedílnou součástí většiny potravin a krmiv. V posledních letech se stále více zaměřuje pozornost na jejich dietetické a zdravotní účinky o nichž rozhoduje především obsah a vzájemné poměry jednotlivých mastných kyselin. V uvedené studii jsme se zaměřili na porovnání vlivu př́ídavku šesti rostlinných olejů do krmných směsí pro brojlery 
na zastoupení mastných kyselin v prsní a stehenní svalovině jako vhodný zdroj zejména n-3 a n-6 mastných kyselin pro lidskou výživu. Do pokusu bylo zařazeno celkem 90 jednodenních kohoutků typu Ross 308 rozdělených do šesti skupin krmených směsmi typu - BR 1, BR 2 a BR 3. V krmné směsi BR 1, která byla podávána všem šesti skupinám po dobu prvních 10 dnů výkrmu byl obsažen sojový olej. Do krmných směsí BR 2, která byla krmena od 11 . dne do 30. dne věku a BR 3 podávané brojlerům od 31. dne do ukončení pokusu, tj. 42. den, byly jednotlivým skupinám kưrat přidány rostlinné oleje (skupina 1. - sojový, 2. - řrepkový, 3. - slunečnicový, 4. - lněný, 5. - olivový a 6. - pupalkový olej). Použité rostlinné oleje se odlišovaly zastoupením MK, především kyselinami olejovou, linolovou, $\alpha$-linolenovou. Zkrmování uvedených experimentálních diet, od 11. do 42. dne věku kuřat, významně ovlivnilo zastoupení vybraných MK v tuku prsní a stehenní svaloviny. Významně vyšší $(p \leq 0,01)$ byl obsah kyseliny $\alpha$-linolenové v prsní a stehenní svalovině brojlerů, přijímajících dietu se lněným olejem $(21,16$ g/100 g, resp. 17,13 g/100 g oleje). Nejvyšší zastoupení kyseliny linolové $(p \leq 0.01)$ v prsní i stehenní svalovině bylo zjištěno u kuřat přijímajících dietu s pupalkovým olejem $(59,13 \mathrm{~g} / 100 \mathrm{~g}$, resp. 51,71 g/100 g). Významně vyšší $(p \leq 0,01)$ zastoupení kyseliny olejové bylo zjištěno $\mathrm{v}$ obou svalovinách brojlerů, krmených dietou s olivovým olejem $(52,44 \mathrm{~g} / 100 \mathrm{~g}$, resp. 43,70 g/100 g oleje). U kyseliny palmitové, palmitoolejové významné změny zaznamenány nebyly. Mezi hladinami kyseliny olejové, linolové a $\alpha$-linolenové v krmných směsích a jejich koncentracemi v prsní a stehenní svalovině byly nalezeny vysoce významné korelace ( $\mathrm{r}=0,88 ; 0,94$ a 0,99 , resp. $\mathrm{r}=0,99 ; 0,98$ a 0,99$)$.

\section{Acknowledgements}

Financial support from the Ministry of Education, Youth, and Sports of the Czech Republic (Grant No MSMT 6215712402) is gratefully acknowledged.

\section{References}

Aldai N, Dugan MER, Najera AI, Osoro K 2008: N-6 and n-3 fatty acid in different beef adipose tissues depending on the presence or absence on the gene responsible for double-muscling. Czech J Anim Sci 56: 512-522

Barton L, Marounek M, Kudrna V, Bures D, Zahradkova R 2007: Growth performance and fatty acid profiles of intramuscular and subcutaneous fat from Limousin and Charolais heifers fed extruded linseed. Meat Sci 76: 517-523

Barton L, Marounek M, Kudrna V, Bures D, Zahradkova R 2008: Growth, carcass traits, chemical composition and fatty acid profile in beef from Charolais and Simmental bulls fed different types of dietary lipids. J Sci Food Agr 88: 2622-2630

De Henauw S, Van Camp J, Sturtewagen G, Matthys C, Bilau M, Warnants N, Raes K, Van Oeckel M, De Srnet S 2007: Simulated changes in fatty acid intake in humans through n-3 fatty acid enrichment of foods from animal origin. J Sci Food Agr 87: 200-211

Du M, Ahn DU 2003: Dietary CLA affects lipid metabolism in broiler chicks. Lipids 38: 505-511

Hara A, Radin NS 1978: Lipid extraction of tissues with a low-toxicity solvent. Anal Biochem 90:420-426

Kim YJ, Kim BK, Yoon YB 2008: Effect of dietary conjugated linoleic acid on growth performance, carcass characteristics and muscular fatty acid composition in broiler. Korean J Food Sci Anim Resour 28: 451-456

Lands WEM, Libett B, Morris A, Kramer NC, Prewitt TE, Bower P, Schneisser D, Davidson MH, Burns JH 1992: Maintenance of lower proportions of (n-6) eicosanoid precursors in phospholipids of human plasma in response to added dietary (n-3) fatty acids. BBA-Mol Basis Dis 1180: 147-162

Leeson SE, Summers JD 2005: Commercial Poultry Nutrition. University Books, Guelp, Ontario. 398 p.

Okuyama H, Kobayashi T, Watanabe S 1997: Dietary fatty acid - the n-6/n-3 balance and chronic elderly disease. Excess linoleic acid and relative n-3 deficiency syndrome seen in Japan. Prog Lipid Res 35: 409-457

Schiavone A, Ramboli I, Chiarini R, Marzoni M 2004: Influence of dietary lipid source and strain on fatty acid composition of Muscovy duck meat. J Anim Physiol An N 88: 88-93

Simopoulos AP 1999: Essentials fatty acid in health and chronic disease. Am J Clin Nutr 70: 560-569

Sirri F, Tallarico N, Meluzzi A, Franchini A 2003: Fatty acid composition and productive traits of broiler fed diets containing conjugated linoleic acid. Poultry Sci 82: 1356-1361

Skrivan M, Skrivanova V, Marounek M, Tumova E, Wolf J 2000: Influence of dietary fat source and copper supplementation on broiler performance, fatty acid profile of meat and depot fat, and on cholesterol content in meat. Br Poultry Sci 41: 608-614

STATSOFT Inc. 2001: STATISTICA for Windows Version 6 (Computer Program Manual)

Thacker PS, Campbell GL, Xu Y 1994: Composition and nutritive value of acidulated fatty acids, degummed canola oils and tallow as energy sources for starting broiler chicks. Anim Feed Sci Tech 46: 251-260 
WHO 2003: Diet, nutrition and the prevention of chronic diseases. WHO Technical Report Series 916. Geneva. 149p. ISBN $924120916 \mathrm{X}$

Wiseman J, Powles J, Salvador F 1998: Comparison between pigs and poultry in the prediction of the dietary energy value of fats. Anim Feed Sci Tech 71: 1-9

Zelenka J, Schneiderová D, Mrkvicová E, Doležal P 2008: The effect of dietary linseed oils with different fatty acid pattern on the content of fatty acids in chicken meat. Vet Med-Czech 53: 77-85

Zollitsch W, Knaus W, Aichinger F, Lettner F 1997: Effects of different dietary fat sources on performance and carcass characteristics of broilers. Anim Feed Sci Technol 66: 63-73 